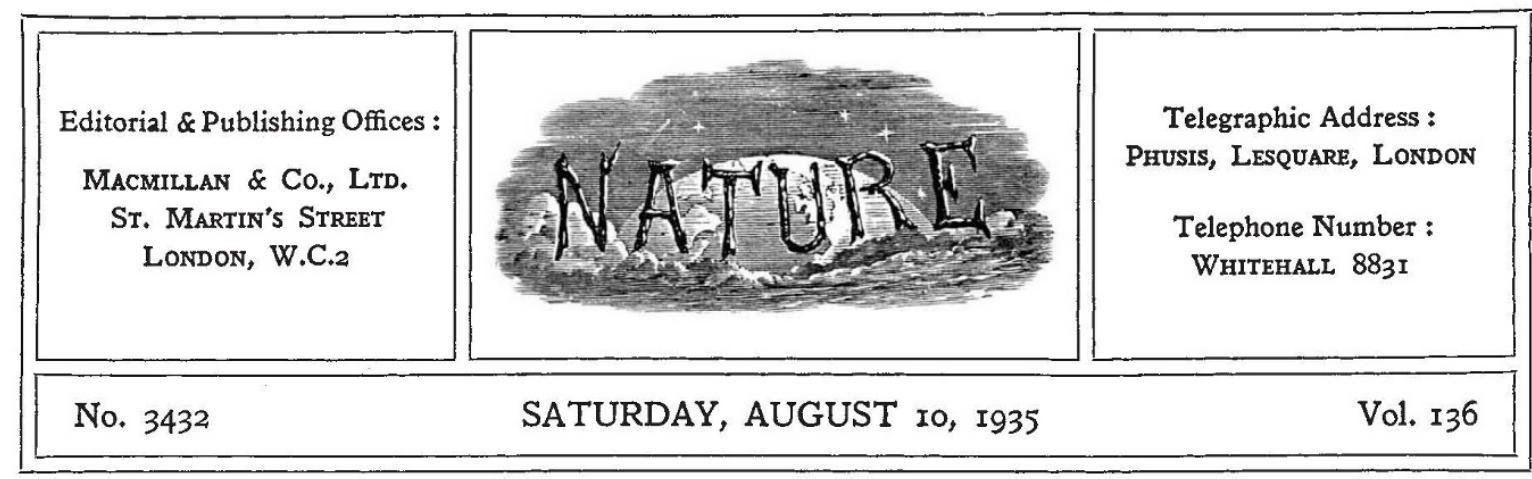

\title{
The Future of British Agriculture
}

$\mathrm{A}^{\mathrm{T}}$ a time like the present, when radical I changes are taking place or being contemplated in our national economy, when countries like Great Britain, Holland and Denmark are abandoning the policy of Free Trade and venturing on the thorny paths of Protection and national self-sufficiency, efforts to discern the future acquire an interest and importance that far outweigh the vaticinations of those who don the prophet's mantle in more settled and humdrum times. History, we know, is replete with the misjudgments and miscalculations of statesmen and politicians who, besides having to deal with the incalculable in human nature, have also been handicapped by lack of scientific training and outlook; and the question is now frequently asked whether men trained in the methods and content of science could not do better? So far, they have seldom been called upon to act, or even to advise, in the affairs of State; and it is not certain that, had they been asked, they would have been more successful than their contemporary statesmen, trained in the law, the humanities or in business. Are the views of scientifically trained men on political, economic, social, religious and philosophical questions more far-sighted, more reasoned and less biased by traditional beliefs and emotional prejudices than those of others?

We believe that a general vote on this question would result in a decided 'No': and the main reasons for the answer would be that the scientific mind, like the artistic, generally runs in grooves, and the methods that are applied so fruitfully in the positive sciences are either not applied, or if used are misapplied, in those spheres which to a large and regrettable extent are still dominated by instinct and desire rather than by reason and the public good. Although the doctrine that mental ability acquired in one sphere is not transferable to another unless the subject matter is correlated, seems to apply here, a case can be made out that scientific habits of mind, such as initial doubt, careful testing of fundamental assumptions and evaluation of evidence, do come within the category of transferable qualities. If this is so, it affords an additional reason why those engaged in scientific pursuits should seek to pull their weight in the social boat by using their talents in trying to solve some of the pressing social and economic questions that now await solution.

Prediction, based upon generalised knowledge of natural facts, is one of the major, and perhaps the most useful of the functions of science : we know how well it succeeds in the strictly mathematical sciences and in certain applied sciences like astronomy and engineering, but in agriculture, which is a congeries of applied sciences still largely dominated by tradition and empiricism, prediction is far more difficult ; there are so many variables ; the weather and the human factor between them upset many a calculation. Some measure of sympathy must therefore be extended to Sir John Russell, who, in his recent discourse at the Royal Institution on the future of British agriculture, set himself a very difficult task. Many eminent persons, he remarked, had lost their well-earned reputations by dabbling in the future, but in these critical times, one had to take risks; and the safer method was to base one's predictions on present trends and movements.

Among the unchanging elements in our agricultural economy, Sir John Russell mentioned the present regional distribution of crops, which is determined largely by climate and soil; it is, 
however, an interesting fact that all our crops, excepting sugar-beet, hops and lucerne, are grown in every county, and it seems to us quite possible that efficiency in production and distribution might be increased by introducing some measure of rationalisation. According to free-trade principles, each country should grow what it is best fitted to grow, and exchange its excess for foreign products which it wants. Might not the same principle be applied to regions within a country ? And is it not time to contemplate the subdivision of the country into regions that would take the place of the counties, many of which are very small and some minute, and in this way save expenditure on administration? We may yet live to see established a modern form of the old AngloSaxon heptarchy.

The sturdy, independent and strongly individualistic character of the English farmer will, Sir John suggested, remain as a bulwark against collectivist tendencies in the population, and that is to the good, because State supervision failed during the late War: it failed in France in the Revolution, and it is proving a failure in Russia now. Further, the English countryman's attachment to animals (however fond he may be of killing them !) will ensure that the production of animals and milk will continue to form the major part of his occupation; he is also likely to retain his love of craftsmanship and his dislike of mass production methods. Thanks to the development of agricultural education, there is arising a generation of farmers who are keener, more alert and more anxious to make the best of their farms than were their predecessors.

Implied in Sir John Russell's prognostications is the improbability of any really fundamental changes taking place in our political and economic structure. Our present individual farming, he holds, will persist, and continue to be of the small capitalist type that now occupies about one half of our farm-holdings with an area varying from 100 to 300 acres. There is, however, a prominent school of agricultural thought, of which Mr. C. S. Orwin, of the University of Oxford, is an able exponent, which believes that nationalisation of the land will follow as a direct consequence of our present parlous agricultural conditions. The old partnership relations of landlord and tenant have disappeared; the landlord has lost most of his capital and can no longer undertake the duties which that partnership imposed upon him. The land is crying out for fresh capital-for drainage, water supplies, farm equipment and housing-and if the changes which this school sees coming are brought about, namely, an increase in familyfarms on one hand, and in large-scale, mechanised and specialised farms on the other, the call for new capital will be greater than ever. As an economic necessity, the State must take over the land, provide the necessary capital, but not necessarily control the farming practice.

It is not always realised that the vast majority of the world's farming is done by the peasant class-small men with little or no capital, whose standard of living is low compared with that of industrial workers, who are gluttons for work, and to whom agriculture is a mode of life rather than a money-making occupation. Although this type of farming cannot as a rule compare in economy and efficiency with the large-scale mechanised type, nevertheless it is encouraged by practically all Governments, because it represents an element of stability in the State: family-farmers are selfsupporting in times of depression and they constitute a reserve of man-power in time of war. Even highly industrialised nations like Great Britain have been constrained to encourage this type, though not always with success. In this connexion, Sir John Russell points out that the main difficulties are concerned with marketing and leadership, and he does not believe that we should succeed in establishing co-operative colonies of smallholders on the highly successful lines of Denmark; he envisages rather a type of land settlement, self-contained and self-supporting, in which living, not selling, is the leitmotiv, each unit producing what it can and bartering its excess for commodities it does not produce. Some experiments of this kind are being made in England; they have been successful in French Canada, in other parts of the British Empire, and in the United States, but in nearly every case the settlers have been drawn together and united by a spiritual bond, such as the Church.

The factory type of farming, which is based on mechanisation of agricultural operations and specialisation in the growing of only one or two crops, is obviously the more economical in man and horse labour, but is not of such general application. Sir John Russell stated that the ordinary system of English farming requires 25-30 permanent employees per square mile, whereas on a highly mechanised farm in Saskatchewan one man per square mile suffices. The case for the development of factory farms and of 
small holdings has been ably expounded by Mr. C. S. Orwin in his book on "The Future of Farming" (Oxford University Press, 1930), but his conclusions appear to be in direct opposition to Sir John Russell's prediction that the mediumsized farm owned by the small capitalist will continue to prevail in Great Britain.

If it cannot be admitted that British agriculture has grown and developed continuously from very early times, progress was catalysed by the coming of the industrial era and the fear of starvation during the Napoleonic wars. The growing of turnips, clover and rotation grasses, which did not become general until more than a hundred years after the idea had been introduced from Flanders ; the improvements in livestock due to Bakewell, the brothers Colling, Thomas Bates and others; and later the use of artificial fertilisers and the breeding of new varieties and strains of economic plants, have all contributed their quotas to the great increases in production that were rendered necessary by tremendous growth in population. As in industry, the problem of production seems very largely to have been solved; the most urgent problems now are those of distribution and quality of product.

In Great Britain, however, the problem of increased production is still with us, for owing to our greatly reduced income from the export of goods and services and investments overseas, not to mention possible international complications, expert opinion is now generally agreed that we must grow more food at home. Sir John Russell agrees that our present output of $36-40$ per cent of the nation's food supply is too low, and he asks for an impartial inquiry to be conducted by technical and business experts, and representatives of the Ministry of Agriculture, the Foreign, Colonial and Dominions Offices, who would advise where the line should be drawn. A question embodying this timely suggestion was asked in the House of Commons on July 15, when the Minister of Agriculture replied that it was not acceptable, but the Government was fully alive to the question of domestic production of food in relation both to the interests of agriculture and to the general economy of the country. It would appear that the Prime Minister and the Cabinet are not enamoured of deliberate long-term planning; their agricultural quiver seems to be fully charged with the intricate and delicate problems associated with the working of the various marketing boards, which were launched with the entirely praiseworthy object of securing an economic return to the producer. In Sir John Russell's view, the ordered development of British agriculture involves deciding how much should be produced at home ; and he favours the contract system, with obligations on both sides, including the social obligation of paying a living wage to the workers. That system works well for milk, sugar-beet and bacon, but it is not applicable to produce like beef, mutton, potatoes, eggs, which are handled by a multitude of small distributors. The problem of distribution, it is generally conceded, is of outstanding importance, and no Government that does not tackle it resolutely and impartially is worthy of our support.

The history of British agriculture shows that although men of enlightenment have seldom been lacking, progress has usually been extremely slow, owing to the crusted conservatism of the farming population. In the last hundred years, science has done wonders in giving the farmer the means to increase production, but although he has used them to some extent, the potentialities, especially of fertilisers and of scientific breeding, still remain very great. In the past, the greatest spur to progress has always been economic necessity, and as this is now again in the ascendant, it seems probable that, at any rate in the near future, changes in our economic system generally are likely to play a greater part than the application of new scientific discoveries. When we reflect that about one quarter of our population is living to-day on or under the border-line of poverty, that the average income of 75 per cent of our

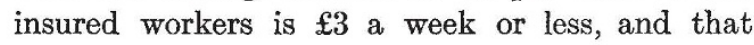
about 70 per cent of those who died in 1933-34 left no more than $£ 100$, or less, we cannot be surprised at the economic unrest that obtains in so many quarters. Until some solution or amelioration of the problem of the existence of poverty amidst plenty is forthcoming, substantial national progress seems out of the question.

The Chancellor of the Exchequer may derive satisfaction from the statement that "we" have recovered 80 per cent of our prosperity, and that "we meet in an atmosphere of such happiness and contentment as has not been seen since the War" (as he told the bankers in a recent post-prandial speech), but such assertions do not help the cause of social peace and development ; rather do they, by substituting illusion and self-satisfaction for ascertainable fact and self-suppression, reflect an attitude of mind which is the negation of the realistic spirit of all true science. 